\title{
Does commercial probiotics improve the growth performance and hematological parameters of Nile tilapia, Oreochromis niloticus?
}

\author{
Rashedul HASAN, Mohammad Amzad HOSSAIN, Md. Rashedul ISLAM, Mohammed Mahbub IQBAL
}

Cite this article as:

Hasan, R., Hossain M.A., Islam, Md.R., Iqbal, M.M. (2021). Does commercial probiotics improve the performence and hemetological parameters of Nile tilapia, Oreochromis niloticus? Aquatic Research, 4(2), 160-168. https://doi.org/10.3153/AR21013

${ }^{1}$ Sylhet Agricultural University, Faculty of Fisheries, Department of Fish Biology and Genetics, Sylhet-3100, Bangladesh.

ORCID IDs of the author(s): R.H. 0000-0001-6781-965X M.A.H. 0000-0001-9219-3628 Md.R.I. 0000-0002-7864-8021 M.M.I. 0000-0001-5720-4029

Submitted: 26.09 .2020

Revision requested: 28.10 .2020

Last revision received: 13.11 .2020

Accepted: 13.11 .2020

Published online: 03.03.2021

\begin{abstract}
Oreochromis niloticus becoming a promising aquaculture species globally, but recent disease outbreaks and poor growth with commercial feed making it challenging. A 60 days long aquarium trial and series of laboratory assays have been conducted to assess the growth performance of $O$. niloticus fed with a locally available commercial probiotic. $O$. niloticus fry's were fed with a mixture of basal diet and probiotics supplementation at a level of $0 \%$ (control), $0.2 \%, 0.4 \%$ and $0.8 \%$. After the trial phase weight gain, length gain, specific growth rate (SGR), percentage of weight gain (PWG), percentage of length gain (PLG) were noted. Among all, highest values of above parameters were observed at $\mathrm{T}_{1}(0.2 \%)$ treatment group. Weight gain, length gain, PLG and PWG were significantly improved in $\mathrm{T}_{1}$ treatment group $(\mathrm{p}<0.05)$. Additionally, hematological parameters including hemoglobin ( $\mathrm{Hb}$ ), white blood cell (WBC) and red blood cell (RBC) were also observed for all groups and $T_{1}$ was found to have highest values for all these parameters, although there were no statistically significant differences between the values of $T_{1}$ and $T_{2}$. The results of this study showed that $0.2 \%$ dietary probiotics supplements in basal diet would optimize the growth performance and hematological parameters of aquarium reared $O$. niloticus.
\end{abstract}

Keywords: Probiotics, Growth performance, Hematological parameters, Oreochromis niloticus

\section{Correspondence:}

Mohammad Amzad HOSSAIN

E-mail: mamzad.fbg@sau.ac.bd

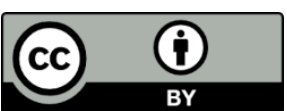

(C) 2021 The Author(s) 


\section{Introduction}

A native fish group of Africa continent, tilapias are among the most practiced species in aquaculture industry worldwide as well as in Bangladesh (Alam et al., 2014; Akter et al., 2019) due to their high productivity rate, disease tolerance and flesh quality (Yuan et al., 2017; Gabriel, 2019;). The commercial hatcheries in Bangladesh produced all male mono-sex fry to adopt rapidly growth rate as well as to reduce undesirable reproduction in culture pond (Lind et al., 2015; Das et al., 2019). Use of chemicals, hormones, drugs and probiotics are getting very popular among aquaculture practices in Bangladesh (Uddin et al., 2017). The need for high-quality fish feeds with a premium protein content, associated nutrients and minerals; which is tasty, keeps animals healthy and providing a high growth rate is increasing (Soltan et al., 2016; Hua et al., 2019; Yue et al., 2020). Probiotics are combination of live microorganisms that are efficient to adapt, colonize and grow within the gut of the host and develop a beneficial stability of microorganisms to improve animals health (Martínez Cruz et al., 2012; Carbone \& Faggio, 2016). Numerous benefits of probiotics for growth, defense and intestinal health of the host were revealed and broad use of probiotics in aquaculture could prevent diseases, promote growth and reduce the extensive use of antibiotic (Austin \& Austin, 2016). Probiotics retard or completely inhibit the growth of pathogenic bacteria following a competitive exclusion (Akayli et al., 2016), also boost up the immune response and secretion of mucosal enzymes to promote host growth and they do not cause secondary pollution problems (Xia et al., 2020). Variations in fish blood parameters would be a good pointer of water quality, nutrition and health (Satheeshkumar et al., 2012; Ahmed et al., 2020). Alterations in hematological parameters are due to the result of stress condition such as hypoxia, contact to pollutants, transportation, handling and liberation of energy associated with the use of chemicals and anesthetics (Roche \& Bogé, 1996; Fazio et al., 2015; Simide et al., 2016). Therefore, the present research was directed towards the evaluating the growth of $O$. niloticus fed with dietary probiotics as well as determining the optimum supplementation level to produce an effective diet, which would provide a favorable physiological condition to culture this species commercially in Bangladesh.

\section{Material and Methods}

\section{Experiment Designing and Diet Preparation}

A 60 days long trial have been conducted in 140 litre glass aquaria. The experiment was designed with four treatments designated with three replications as well. A commercial floating fish feed (moisture 11\%, protein $40 \%$, lipids $6 \%$, carbohydrate $25 \%, 450$ fiber $5 \%$, ash $10 \%$, calcium $2 \%$ and phosphorous $1 \%$ ) was used. A commercial probiotics mixture (AquaStar growout powder; Renata animal health Ltd. Bangladesh) that contains Bacillus, Enterococcus, Pedicoccus and Lactobacillus sp. bacteria was added in diets of experiments groups with a rate of $0 \%(\mathrm{Tc}), 0.2 \%(\mathrm{~T} 1), 0.4 \%$ (T2) and $0.8 \%$ (T3). Tilapia (O. niloticus) fry's were acclimated to laboratory conditions for 14 days and fed only with commercial feed. Then twenty fish with a mean weight of $1.72 \pm 0.42 \mathrm{~g}$ were randomly allotted into each aquarium. They were fed three times a day at $6 \%$ of their body weight at the first month of experiment and gradually reduced to $5 \%$ in the second month. Underground freshwater which was stored in a reservoir and supplied to the aquaria. Each aquarium was equipped with automated aeration and internal carbon filtration facilities. Uneaten feed and the waste materials of aquarium were siphoned out twice per day and approximately 20 percent water was exchanged every two days to keep the water environment suitable for fish survival.

\section{Monitoring Water Quality Parameters and Fish Sampling}

Various water quality parameters such as temperature (with a simple thermometer), dissolved oxygen (YSI digital DO meter, model 58) and $\mathrm{pH}$ (pH meter - Hanna Instruments, Japan) in each aquarium was monitored once in a week during the experiment period. Every 15 days, three fishes from each aquarium were sampled randomly in all treatments groups for length and weight gain after a 24 hours starvation period.

\section{Analysis of Growth Parameters}

At the end of the feeding trial various growth parameters were analyzed by using the mathematical formula according to Olvera-Novoa et al., (1990), Panase \& Mengumphan, (2015) and Pechsiri \& Yakupitiyage, (2005).

Weight gain= Mean value of final weight- Mean value of initial weight

Percentage of weight gain

$=$ $\frac{\text { Mean value of final fish weight-Mean value of initial fish weight }}{\text { Mean value of initial fish weight }} \times 100$

Specific growth rate SGR $(\%)=\frac{\ln \mathrm{W} 2-\ln W 1}{T 2-T 1} \times 100$, Where $\mathrm{W}_{1}=$ the initial body weight $(\mathrm{gm})$ at a time, $\mathrm{W}_{2}=$ the final body weight $(\mathrm{gm})$ at a time, $\mathrm{T}_{2}-\mathrm{T}_{1}=$ Duration in days

Length gain=Mean value of final length- Mean value of initial length 
Percentages of length gain

$=\underline{\text { Mean value of final fish length }- \text { Mean value of initial fish length }} \times$ Mean avlue of initial fish length

100

Average daily weight gain

$=\underline{\text { Mean value of final weight }- \text { Mean value of initial weight }}$ Duration of experiment in days

Average daily length gain

Mean value of final length-Mean value of initial length Duration of experiment in days

The values of Fulton's condition factor $(\mathrm{K})$ was estimated by plotting length weight data on the following equation adopted from Htun-Han, (1978); $\mathrm{K}=\left(\mathrm{W} / \mathrm{L}^{3}\right) * 100$

\section{Blood Sample Collection and Hematological Analysis}

Blood samples were collected (3 fishes from each group) after a 24 hours starvation period from the caudal vena and stored in EDTA (Ethylene diamine tetra-acetic acid). Hemoglobin, WBC, and RBC analysis was carried out by using Automated Hematology Analyzer BC-3000 Plus.

\section{Data Analysis}

The one-way analysis of variance (ANOVA) and Duncan's multiple Range Test (DMRT) were conducted to figure out the differences among the groups means at significance level of $\mathrm{P}<0.05$. All statistics were carried out using Statistical Package for Social Science (IBM SPSS) version 22.

\section{Results and Discussion}

In this study tilapia fry were feed with a standard commercial feed and with the addition of various amounts of a probiotic mixture and the differences in growth and blood parameters in fish were revealed.

Water quality parameters are vital as they influence the growth and physiological activities of fish (Maucieri et al., 2019). Temperature is a key factor for the production management and feed consumption in fish. The optimal thermal range for the proper growth of $O$. niloticus was proposed as $25-27^{\circ} \mathrm{C}$ (Makori et al., 2017) and 27-32 ${ }^{\circ} \mathrm{C}$ (Mengistu et al., 2020). Dissolved oxygen, which is a crucial factor for fish growth, health, and physiology should be over $5 \mathrm{mg} / \mathrm{L}$ for sustainable growth of $O$. niloticus (Riche \& Garling, 2003; Makori et al., 2017). pH is an imperative factor which specifies the health and production output of a water body and optimum range was proposed as 5.5-9.0 (Rebouças et al., 2016) and 6.1-8.3 (Makori et al., 2017) for O. niloticus. Water quality parameters i.e., temperature, dissolved oxygen (DO) and $\mathrm{pH}$ observed during the study were shown in Table 1 . These results showed that the water quality parameters were appropriate for $O$. niloticus culture.

Among four experimental groups fed with basal commercial feed and probiotic mixture - $0 \%$ (Tc), $0.2 \%$ (T1), $0.4 \%$ (T2) and ), $0.8 \%$ (T3) - maximum mean weight gain was detected in $\mathrm{T}_{1}(16.1975 \pm 3.16 \mathrm{~g})$ followed by $\mathrm{T}_{2}(12.79 \pm 3.16 \mathrm{~g})$ and $\mathrm{T}_{3}$ $(10.326 \pm 2.47 \mathrm{~g})$ respectively (Table 2$)$. The lowest mean weight was observed in $\mathrm{T}_{\mathrm{C}}(8.23 \pm 1.83 \mathrm{~g})$ and the means of the weight gains among all the treatments groups were significantly varied between each other $(\mathrm{P}<0.05)$. Among the groups, $\mathrm{T}_{1}(0.2 \%)$ showed the highest weight gain and $\mathrm{T}_{\mathrm{C}}$ $(0 \%$, Probiotic) showed the lowest growth performance. The mean percentages of weight gain (PWG) in $O$. niloticus was recorded in $\mathrm{T}_{\mathrm{C}}\left(478.86 \pm 204.86^{\mathrm{a}}\right), \mathrm{T}_{1}(981.52 \pm 382.27), \mathrm{T}_{2}$ $(863.31 \pm 339.98)$ and $\mathrm{T}_{3}(702.09 \pm 298.95)$ (Table 2). Highest mean PWG was found in $T_{1}$ followed by $T_{2}, T_{3}$ and $T_{C}$, respectively. However, difference between $T_{2}$ and $T_{3}$ $(\mathrm{P}>0.05)$ were statistically uniform and the lowest mean PWG was observed in control treatment. Specific Growth Rate (SGR\%) of O. niloticus was recorded as $2.83 \pm 0.55$, $3.87 \pm 0.57,3.68 \pm 0.56$ and $3.36 \pm 0.62$ in $\mathrm{T}_{\mathrm{C}}, \mathrm{T}_{1}, \mathrm{~T}_{2}$ and $\mathrm{T}_{3}$ groups respectively (Table 2). Highest SGR value (3.87 \pm 0.57 ) was observed in $T_{1}$ while the lower SGR value was recorded in $\mathrm{T}_{\mathrm{C}}(2.83 \pm 0.55)$ group. The differences between $\mathrm{T}_{1}, \mathrm{~T}_{2}, \mathrm{~T}_{2}$ and $\mathrm{T}_{3}$ diet groups $(\mathrm{P}>0.05)$ remained still statistically non-significant.

The mean length gain of $O$. niloticus was recorded as 4.38 $\pm 0.84 \mathrm{~cm}, 8.02 \pm 1.09 \mathrm{~cm}, 5.93 \pm 0.94 \mathrm{~cm}$ and $5.18 \pm 1.03 \mathrm{~cm}$ in $T_{C}, T_{1}, T_{2}$ and $T_{3}$ groups respectively (Table 2 ). The length gain was increased in $T_{1}$ groups followed by $T_{2}, T_{3}$ and $T_{C}$ groups, respectively. The highest mean length was observed in $T_{1}$ diet group whereas the control group $\left(T_{C}\right)$ showed the lowest mean length gain during 60 days of experiment. The difference among all groups were significant at $\mathrm{P}<0.05$. The highest percentages of length (PLG) were observed as 184.44 \pm 48.27 in $\mathrm{T}_{1}$ groups followed by $\mathrm{T}_{2}, \mathrm{~T}_{3}$ and $\mathrm{T}_{\mathrm{C}}$ groups, respectively. PLG (\%) values $141.33 \pm 36.84$ and $120.04 \pm 33.94$ were recorded in $\mathrm{T}_{2}$ and $\mathrm{T}_{3}$ groups respectively (Table 2). $\mathrm{T}_{\mathrm{C}}(102.37 \pm 25.38)$ group showed the lowest percentage of length gain. $T_{1}$ group showed a significant difference than the other treatment but there is no significant difference between $T_{2}$ and $T_{3}$ groups $(\mathrm{P}>0.05)$ in terms of percentage length gain. 
Table 1. Mean value of water quality parameters (Mean Value \pm SD)

\begin{tabular}{lcccc}
\hline \multirow{2}{*}{ Water quality parameter } & \multicolumn{4}{c}{ Experiment groups } \\
\cline { 2 - 5 } & $\mathbf{T}_{\mathbf{C}}(\mathbf{c o m m e r c i a l}$ feed only) & $\mathbf{T}_{\mathbf{1}} \mathbf{( \mathbf { 0 . 2 } \% \text { probiotics} )}$ & $\mathbf{T}_{\mathbf{2}} \mathbf{( 0 . 4 \%}$ probiotics) & $\mathbf{T}_{\mathbf{3}} \mathbf{( \mathbf { 0 . 8 } \% \text { probiotics} )}$ \\
\hline Temperature $\left({ }^{\circ} \mathbf{C}\right)$ & $26.33 \pm 1.03^{\mathrm{a}}$ & $26.67 \pm 1.03^{\mathrm{a}}$ & $26.67 \pm 0.81^{\mathrm{a}}$ & $26.5 \pm 1.04^{\mathrm{a}}$ \\
\hline Dissolved oxygen $(\mathbf{m g} / \mathrm{L})$ & $5.33 \pm 0.21^{\mathrm{a}}$ & $5.55 \pm 0.08^{\mathrm{a}}$ & $5.35 \pm 0.16^{\mathrm{a}}$ & $5.41 \pm 0.12^{\mathrm{a}}$ \\
\hline pH & $7.43 \pm 0.08^{\mathrm{a}}$ & $7.6 \pm 0.30^{\mathrm{a}}$ & $7.5 \pm 0.28^{\mathrm{a}}$ & $7.4 \pm 0.08^{\mathrm{a}}$ \\
\hline
\end{tabular}

Table 2. Growth parameters of $O$. niloticus after 60 days treatment (means \pm standard deviation) $(\mathrm{P}>0.05)$

\begin{tabular}{|c|c|c|c|c|}
\hline \multirow{2}{*}{ Parameters } & \multicolumn{4}{|c|}{ Experiment groups } \\
\hline & $\mathbf{T}_{\mathrm{C}}$ (commercial feed only) & $T_{1}(0.2 \%$ probiotics $)$ & $T_{2}(0.4 \%$ probiotics $)$ & $T_{3}(0.8 \%$ probiotics $)$ \\
\hline Mean Initial Weight (g) & $1.90 \pm 0.56^{\mathrm{a}}$ & $1.79 \pm 0.45^{\mathrm{a}}$ & $1.59 \pm 0.42^{\mathrm{a}}$ & $1.59 \pm 0.36^{\mathrm{a}}$ \\
\hline Mean Initial Length (cm) & $4.36 \pm 0.49^{\mathrm{a}}$ & $4.46 \pm 0.50^{\mathrm{a}}$ & $4.30 \pm 0.49^{\mathrm{a}}$ & $4.42 \pm 0.44^{\mathrm{a}}$ \\
\hline Mean Final Weight (g) & $10.13 \pm 1.92^{\mathrm{a}}$ & $17.99 \pm 3.01^{\mathrm{d}}$ & $14.38 \pm 3.11^{\mathrm{c}}$ & $11.92 \pm 2.31^{\mathrm{b}}$ \\
\hline Mean Final Length (cm) & $8.75 \pm 0.81^{\mathrm{a}}$ & $12.48 \pm 0.83^{\mathrm{d}}$ & $10.23 \pm 0.73^{\mathrm{c}}$ & $9.60 \pm 0.76^{\mathrm{b}}$ \\
\hline Weight Gain (g) & $8.23 \pm 1.83^{\mathrm{a}}$ & $16.19 \pm 3.16^{\mathrm{d}}$ & $12.79 \pm 3.16^{\mathrm{c}}$ & $10.32 \pm 2.47^{b}$ \\
\hline Length Gain (cm) & $4.38 \pm 0.84^{\mathrm{a}}$ & $8.02 \pm 1.09^{\mathrm{d}}$ & $5.93 \pm 0.94^{\mathrm{c}}$ & $5.18 \pm 1.03^{\mathrm{b}}$ \\
\hline$\%$ Weight Gain & $478.86 \pm 204.86^{\mathrm{a}}$ & $981.52 \pm 382.27^{\mathrm{c}}$ & $863.31 \pm 339.98^{b}$ & $702.09 \pm 298.95^{\mathrm{b}}$ \\
\hline \% Length Gain & $102.34 \pm 25.38^{\mathrm{a}}$ & $184.44 \pm 48.27^{\mathrm{c}}$ & $141.33 \pm 36.84^{\mathrm{b}}$ & $120.04 \pm 33.94^{\mathrm{a}, \mathrm{b}}$ \\
\hline SGR \% & $2.83 \pm 0.55^{\mathrm{a}}$ & $3.87 \pm 0.57^{\mathrm{c}}$ & $3.68 \pm 0.56^{\mathrm{b}, \mathrm{c}}$ & $3.36 \pm 0.62^{b}$ \\
\hline ADWG & $0.13 \pm 0.03^{\mathrm{a}}$ & $0.26 \pm 0.05^{\mathrm{b}}$ & $0.21 \pm 0.05^{\mathrm{c}}$ & $0.17 \pm 0.04^{\mathrm{d}}$ \\
\hline ADLG & $0.07 \pm 0.014^{\mathrm{a}}$ & $0.13 \pm 0.018^{\mathrm{b}}$ & $0.09 \pm 0.015^{\mathrm{c}}$ & $0.086 \pm 0.017^{\mathrm{d}}$ \\
\hline Condition factor, $K$ & $1.78 \pm 0.23^{\mathrm{a}}$ & $1.19 \pm 0.22^{b}$ & $1.39 \pm 0.19^{\mathrm{b}, \mathrm{c}}$ & $1.55 \pm 0.31^{\mathrm{d}}$ \\
\hline
\end{tabular}

$\mathbf{S G R}=$ Specific growth rate, $\mathbf{A D W G}=$ Average daily weight gain, $\mathbf{A D L G}=$ Average daily length gain.

Supplementation of probiotics in the diet of aquatic animal increased enzymatic activity, developed digestive activity, synthesis of vitamins and weight gain which enhance the growth of fish (Reyes-Becerril et al., 2008; Nayak, 2010) and modulate immune response (Giri et al., 2013; Galagarza et al., 2018). The dietary supplementation of probiotic and bacterial cocktails were found to improve the gut immune response, morphology and microbial assemblage of intestine in juvenile Oreochromis niloticus (Ayyat et al., 2014; Yamashita et al., 2017; Xia et al., 2020). In this study, supplementation of probiotics in all experiment groups resulted higher growth than the control group (Table 2). It might be occurred due to proper digestion and better nutrient absorption in the fish body. The optimum probiotic level that resulted high in terms of weight gain $(\mathrm{g})$, length gain $(\mathrm{cm})$, SGR $(\%)$, Percentage of weight gain, percentage of length gain growth of $O$. niloticus was found in $\mathrm{T}_{1}(0.2 \%$ probiotic $)$ diet group. This indicated that the overall better growth performance was found in $\mathrm{T}_{1}$ group. Similar observations have been reported on Labeo rohita (Munirasu \& Ramasubramanian, 2017), Clarias gariepinus (Al-Dohail et al., 2009) and Catla catla (Bandyopadhyay \& Das Mohapatra, 2009). All the above study had proven that growth performance of these fishes was meaningly improved in the diet containing probiotic containing than those in control.
Lower SGR $(\%)$ was observed in $\mathrm{T}_{\mathrm{C}}$ group $(2.83 \pm 0.12 \mathrm{~g})$ but among the probiotics treatments $\mathrm{T}_{3}(3.36 \pm 0.13)$ showed the lowest SGR (\%) rate (Table 2). However, there was no significant improvement among the treatment groups in case of SGR (\%). However, there is possibility of arising different toxic elements along with the secretion of enzyme which may hinder the growth or other parameters of fish (Rahman et al., 2019; Chen et al., 2020) and while using very high dosage of probiotics and better growth performance might not be always associated with higher concentration of the probiotic (Ghosh et al., 2008; Mahmoud et al., 2021). A previous study on same species reported highest weight gain at $0.2 \%$ probiotics dietary supplement group in compared with the control groups (Chowdhury et al., 2020).

The condition factor $(\mathrm{K})$ represent the nature of physical factors and biological regulating the growth of fish and it is found to be influenced by a set of factors including feeding types and stress associated with parasitic and physiological agents (Hartman \& Margraf, 2006; Datta et al., 2013; Shoko et al., 2015; Jisr et al., 2018). The $\mathrm{k}>1$ indicate a healthy environment of animals surroundings (Golam Mortuza \& AlMisned, 2013; Asmamaw et al., 2019;). The value of $\mathrm{k}$ has been reported above 1 and significantly varied between different treatment groups (Table 2), which indicate the quality of water, feed, and animal welfare on current research. 
Hematological parameters represent a better illustration about fish health and environmental monitoring (Eissa \& AbouElGheit, 2014; Dowidar et al., 2018) and they are influenced by various factors including animal's size, growth phase, physiological position, diet and overall environmental circumstances (Cho et al., 2015; Parrino et al., 2018). Highest mean hemoglobin $(\mathrm{Hb})$ value was recorded in $\mathrm{T}_{1}(5.70 \pm 0.17$ $\mathrm{g} / \mathrm{dL})$ compared to $\mathrm{T}_{2}(5.30 \pm 0.30 \mathrm{~g} / \mathrm{dL}), \mathrm{T}_{3}(4.56 \pm 0.20$ $\mathrm{g} / \mathrm{dL})$ and $\mathrm{T}_{\mathrm{C}}(3.76 \pm 0.25 \mathrm{~g} / \mathrm{dL})$ respectively (Table 3$)$. Insignificant differences of $\mathrm{Hb}$ was observed between $\mathrm{T}_{1}$ and $\mathrm{T}_{2}$ groups $(\mathrm{P}>0.05)$. Control group showed a lower level of Hemoglobin. In case of mean white blood cell (WBC) counts, there were also no significant different between $T_{1}$ and $T_{2}$ $(\mathrm{P}>0.05)$. The highest WBC was observed in $\mathrm{T}_{1}$ $\left(10.89 \pm 0.55 \times 10^{4} /\right.$ cumm $)$ followed by $\mathrm{T}_{2}(10.15 \pm 0.64$ $\times 10^{4} /$ cumm) (Table 3$)$. The mean amount of red blood cell (RBC) was higher in $\mathrm{T}_{1}(1.19 \pm 0.06 \mathrm{~m} / \mu \mathrm{L})$ compared to the other groups $(\mathrm{P}>0.05)$ (Table 3$)$. The $\mathrm{T}_{\mathrm{C}}$ groups showed significantly lower level of RBC.
The present research has been revealed that dietary probiotics supplementation increases hemoglobin $(\mathrm{Hb})$, white blood cell (WBC) and red blood cell (RBC) contents in all the groups compared with the control group (Table 3 ). The fish fed with probiotic mixed food became more nutritious due to declined cortisol levels in the plasma haemolymph (Carnevali et al., 2006; Rollo et al., 2006; Al-Dohail et al., 2009) and high cortisol level increase glucose in blood which seems an indicator of physiological stress in fish (Silva et al., 2015). The high level of hemoglobin in fish fed with probiotic might be occurred due to the increasing of iron absorption in blood mediated through releasing acids in gut (Mohapatra et al., 2014; Silva et al., 2015). Firouzbakhsh et al., (2011) stated that a rise in the number of RBC increases the overall hemoglobin concentration in fish blood. In WBC Count $\mathrm{T}_{1}(0.2 \%$, probiotic) and $\mathrm{T}_{2}(0.4 \%$, Probiotic) were insignificantly higher than the other treatments and this blood contents are engaged in modulation of innate immunity via phagocytosis and toxic cell formation (Chico et al., 2018; Puente-Marin et al., 2019). These indicate that the strong immune system might positively affect the health and growth of fish.

Table 3. Blood parameters of O. niloticus in different groups (means \pm standard deviation) $(\mathrm{P}>0.05)$

\begin{tabular}{lcccc}
\hline Parameters & $\mathbf{T}_{\mathbf{C}}$ (commercial feed only) & $\mathbf{T}_{\mathbf{1}} \mathbf{( 0 . 2 \%}$ probiotics) & $\mathbf{T}_{\mathbf{2}}(\mathbf{0 . 4 \%}$ probiotics) & $\mathbf{T}_{\mathbf{3}} \mathbf{( 0 . 8 \%}$ probiotics) \\
\hline $\mathbf{H b}(\mathbf{g} / \mathbf{d L})$ & $3.76 \pm 0.25^{\mathrm{a}}$ & $5.70 \pm 0.17^{\mathrm{c}}$ & $5.30 \pm 0.30^{\mathrm{c}}$ & $4.56 \pm 0.20^{\mathrm{b}}$ \\
\hline $\mathbf{W B C}(\mathbf{x 1 0} / \mathbf{c u m m})$ & $5.58 \pm 1.16^{\mathrm{a}}$ & $10.89 \pm 0.55^{\mathrm{c}}$ & $10.15 \pm 0.64^{\mathrm{c}}$ & $7.64 \pm 2.42^{\mathrm{b}}$ \\
\hline $\mathbf{R B C}(\mathbf{m} / \mathbf{\mu L})$ & $0.70 \pm 0.133^{\mathrm{a}}$ & $1.19 \pm 0.064^{\mathrm{c}}$ & $0.99 \pm 0.056^{\mathrm{b}, \mathrm{c}}$ & $0.76 \pm 0.18^{\mathrm{b}}$ \\
\hline
\end{tabular}

*WBC $=$ White blood Cell, $\mathbf{R B C}=$ Red Blood Cell, $\mathbf{g} / \mathbf{d L}=$ gram $/$ deciliter, $\mathbf{c u m m}=$ cubemeter, $\mathbf{m} / \boldsymbol{\mu L}=\mathrm{million} / \mathrm{microliter}$.

\section{Conclusion}

The present research was conducted for the determination of the optimum probiotics level in feed to obtain to obtain a better growth of $O$. niloticus. The results of this study showed that probiotic had a higher impact on the growth performance and some blood parameters of $O$. niloticus. After considering the overall performance, it can be concluded that $0.2 \%$ dietary probiotics can be the optimum to provide a better growth performance of $O$. niloticus. The addition of this dietary level of this probiotic mixture may be used in commercial culture of this species. In addition, further study should be designed to observe the result of probiotics in addition to other additives on the cultured growth of tilapia as well as other species.

\section{Compliance with Ethical Standard}

Conflict of interests: The authors declare that for this article they have no actual, potential or perceived conflict of interests.

Ethics committee approval: Approved by institutional, regional and national animal ethical statements.

Funding disclosure: -

Acknowledgments: -

Disclosure: - 


\section{References}

Ahmed, I., Reshi, Q. M., Fazio, F. (2020). The influence of the endogenous and exogenous factors on hematological parameters in different fish species: a review. Aquaculture International, 28(3), 869-899.

https://doi.org/10.1007/s10499-019-00501-3

Akayli, T., Albayrak, G., Ürkü, Ç., Çanak, Ö., Yörük, E. (2016). Characterization of Micrococcus luteus and Bacillus marisflavi recovered from common dentex (Dentex dentex) larviculture system. Mediterranean Marine Science, 17(1), 163-169.

https://doi.org/10.12681/mms.1322

Akter, M., Iqbal, M., Hossain, M., Rahman, A., Uddin, S. (2019). Effect of L-arginine on the growth of monosex fingerling Nile tilapia (Oreochromis niloticus L.). Journal of Fisheries and Life Sciences, 4(2), 31-36.

Al-Dohail, M.A., Hashim, R., Aliyu-Paiko, M. (2009). Effects of the probiotic, Lactobacillus acidophilus, on the growth performance, haematology parameters and immunoglobulin concentration in African Catfish (Clarias gariepinus, Burchell 1822) fingerling. Aquaculture Research, 40(14), 1642-1652.

https://doi.org/10.1111/j.1365-2109.2009.02265.x

Alam, M.B., Islam, M.A., Marine, S.S., Rashid, A., Hossain, M.A. (2014). Growth performances of GIFT tilapia (Oreochromis niloticus) in cage culture at the Old Brahmaputra river using different densities. Journal of Sylhet Agricultural University, 1(2)(January), 265-271.

Asmamaw, B., Beyene, B., Tessema, M., Assefa, A. (2019). Length-weight relationships and condition factor of Nile tilapia, Oreochromis niloticus (Linnaeus, 1758) (Cichlidae) in Koka Reservoir, Ethiopia. International Journal of Fisheries and Aquatic Research, Accepted(January), 5-6. www.fishjournals.com

Ayyat, M.S., Labib, H.M., Mahmoud, H.K. (2014). A probiotic cocktail as a growth promoter in Nile tilapia (Oreochromis niloticus). Journal of Applied Aquaculture, 26(3), 208-215.

https://doi.org/10.1080/10454438.2014.934164

Austin, B., Austin, D.A. (2016). Bacterial Fish Pathogens: Disease of Farmed and Wild Fish. (6th ed.) Springer International Publishing AG Switzerland. ISBN 978-3-31932674-0 (eBook).
Bandyopadhyay, P., Das Mohapatra, P.K. (2009). Effect of a probiotic bacterium Bacillus circulans PB7 in the formulated diets: on growth, nutritional quality and immunity of Catla catla (Ham.). Fish Physiology and Biochemistry, 35(3), 467-478.

https://doi.org/10.1007/s10695-008-9272-8

Carbone, D., Faggio, C. (2016). Importance of prebiotics in aquaculture as immunostimulants. Effects on immune system of Sparus aurata and Dicentrarchus labrax. Fish \& Shellfish Immunology, 54, 172-178.

https://doi.org/10.1016/j.fsi.2016.04.011

Carnevali, O., de Vivo, L., Sulpizio, R., Gioacchini, G., Olivotto, I., Silvi, S., Cresci, A. (2006). Growth improvement by probiotic in European sea bass juveniles (Dicentrarchus labrax, L.), with particular attention to IGF1 , myostatin and cortisol gene expression. Aquaculture, 258(1), 430-438.

https://doi.org/10.1016/j.aquaculture.2006.04.025

Chen, X., Zhang, Z., Fernandes, J. M. O., Gao, Y., Yin, P., Liu, Y., Tian, L., Xie, S., Niu, J. (2020). Beneficial effects on growth, haematic indicators, immune status, antioxidant function and gut health in juvenile Nile tilapia (Oreochromis niloticus) by dietary administration of a multistrain probiotic. Aquaculture Nutrition, 26(4), 1369-1382. https://doi.org/10.1111/anu.13094

Chico, V., Puente-Marin, S., Nombela, I., Ciordia, S., Mena, M.C., Carracedo, B., Villena, A., Mercado, L., Coll, J., Ortega-Villaizan, M.D.M. (2018). Shape-shifted red blood cells: A novel red blood cell stage? Cells, 7(4), 31. https://doi.org/10.3390/cells7040031

Cho, H.C., Kim, J.E., Kim, H.B., \& Baek, H.J. (2015). Effects of water temperature change on the hematological responses and plasma cortisol levels in growing of red spotted grouper, Epinephelus akaara. Development \& Reproduction, 19(1), 19-24.

https://doi.org/10.12717/DR.2015.19.1.019

Chowdhury, G., Hossain, M.S., Dey, T., Akhtar, S., Jinia, M. A., Das, B., Islam, M.J., Iqbal, M. M. (2020). Effects of dietary probiotics on the growth, blood chemistry and stress response of pabda catfish (Ompok pabda) juveniles. $A A C L$ Bioflux, 13(3), 1595-1605.

Das, B., Sarker, B., Hossain, A., Alam, M., Iqbal, M.M. (2019). Optimization of $17 \alpha$-methyltestosterone dose to produce quality mono-sex Nile tilapia (Oreochromis 
niloticus). First International Conference on Sustainable Fisheries. Sylhet Agricultural University, Sylhet-3100, Bangladesh, 67.

Datta, S.N., Kaur, V.I., Dhawan, A., Jassal, G. (2013). Estimation of length-weight relationship and condition factor of spotted snakehead Channa punctata (Bloch) under different feeding regimes. SpringerPlus, 2, 436.

https://doi.org/10.1186/2193-1801-2-436

Dowidar, M., Abd ElAzeem, S., Khater, A.M., Awad Somayah, M., Metwally, S.A. (2018). Improvement of growth performance, immunity and disease resistance in Nile tilapia, Oreochromis niloticus, by using dietary probiotics supplementation. Journal of Animal Science and Veterinary Medicine, 3(2), 35-46.

https://doi.org/10.31248/JASVM2018.076

Eissa, N., Abou El Gheit, E. (2014). Dietary Supplementation impacts of potential non-pathogenic isolates on growth performance, hematological parameters and disease resistance in Nile tilapia (Oreochromis niloticus). Journal of Veterinary Advances, 4(10), 712.

https://doi.org/10.5455/jva.20141025045451

Fazio, F., Ferrantelli, V., Fortino, G., Arfuso, F., Giangrosso, G., Faggio, C. (2015). The influence of acute handling stress on some blood parameters in cultured Sea bream (Sparus aurata Linnaeus, 1758). Italian Journal of Food Safety, 4(1), 4174.

https://doi.org/10.4081/ijfs.2015.4174

Firouzbakhsh, F., Noori, F., Khalesi, M.K., Jani-Khalili, K. (2011). Effects of a probiotic, protexin, on the growth performance and hematological parameters in the oscar (Astronotus ocellatus) fingerlings. Fish Physiology and Biochemistry, 37(4), 833-842.

https://doi.org/10.1007/s10695-011-9481-4

Gabriel, N.N. (2019). Review on the progress in the role of herbal extracts in tilapia culture. Cogent Food \& Agriculture, 5(1), 1619651.

https://doi.org/10.1080/23311932.2019.1619651

Galagarza, O.A., Smith, S.A., Drahos, D.J., Eifert, J.D., Williams, R.C., \& Kuhn, D.D. (2018). Modulation of innate immunity in Nile tilapia (Oreochromis niloticus) by dietary supplementation of Bacillus subtilis endospores. Fish \& Shellfish Immunology, 83, 171-179.

https://doi.org/10.1016/j.fsi.2018.08.062
Ghosh, S., Sinha, A., Sahu, C. (2008). Dietary probiotic supplementation in growth and health of live-bearing ornamental fishes. Aquaculture Nutrition, 14(4), 289-299. https://doi.org/10.1111/j.1365-2095.2007.00529.x

Giri, S.S., Sukumaran, V., Oviya, M. (2013). Potential probiotic Lactobacillus plantarum VSG3 improves the growth, immunity, and disease resistance of tropical freshwater fish, Labeo rohita. Fish \& Shellfish Immunology, 34(2), 660-666.

https://doi.org/10.1016/j.fsi.2012.12.008

Golam Mortuza, M., Al-Misned, F.A. (2013). Lengthweight relationships, condition factor and sex-ratio of Nile tilapia, Oreochromis niloticus in Wadi Hanifah, Riyadh, Saudi Arabia. World Journal of Zoology, 8(1), 106-109.

Hartman, K.J., Margraf, F.J. (2006). Relationships among condition indices, feeding and growth of walleye in Lake Erie. Fisheries Management and Ecology, 13(2), 121-130. https://doi.org/10.1111/j.1365-2400.2006.00486.x

Htun-Han, M. (1978). The reproductive biology of the dab Limanda limanda (L.) in the North Sea: Seasonal changes in the ovary. Journal of Fish Biology, 13(3), 351-359.

https://doi.org/10.1111/j.1095-8649.1978.tb03443.x

Hua, K., Cobcroft, J.M., Cole, A., Condon, K., Jerry, D.R., Mangott, A., Praeger, C., Vucko, M. J., Zeng, C., Zenger, K., Strugnell, J.M. (2019). The future of aquatic protein: implications for protein sources in aquaculture diets. One Earth, 1(3), 316-329.

https://doi.org/10.1016/j.oneear.2019.10.018

Jisr, N., Younes, G., Sukhn, C., El-Dakdouki, M.H. (2018). Length-weight relationships and relative condition factor of fish inhabiting the marine area of the Eastern Mediterranean city, Tripoli-Lebanon. The Egyptian Journal of Aquatic Research, 44(4), 299-305.

https://doi.org/10.1016/j.ejar.2018.11.004

Lind, C.E., Safari, A., Agyakwah, S.K., Attipoe, F.Y.K., El-Naggar, G.O., Hamzah, A., Hulata, G., Ibrahim, N.A., Khaw, H.L., Nguyen, N.H., Maluwa, A.O., Zaid, M., Zak, T., Ponzoni, R.W. (2015). Differences in sexual size dimorphism among farmed tilapia species and strains undergoing genetic improvement for body weight. Aquaculture Reports, 1, 20-27.

https://doi.org/10.1016/j.aqrep.2015.03.003

Mahmoud, H.K., Reda, F.M., Alagawany, M., Farag, 
M.R. (2021). Ameliorating deleterious effects of high stocking density on Oreochromis niloticus using natural and biological feed additives. Aquaculture, 531, 735900.

https://doi.org/10.1016/j.aquaculture.2020.735900

Makori, A.J., Abuom, P.O., Kapiyo, R., Anyona, D.N., Dida, G.O. (2017). Effects of water physico-chemical parameters on tilapia (Oreochromis niloticus) growth in earthen ponds in Teso North Sub-County, Busia County. Fisheries and Aquatic Sciences, 20(30), 1-10.

https://doi.org/10.1186/s41240-017-0075-7

Martínez Cruz, P., Ibáñez, A.L., Monroy Hermosillo, O.A., Ramírez Saad, H.C. (2012). Use of probiotics in aquaculture. ISRN Microbiology, 2012, 916845.

https://doi.org/10.5402/2012/916845

Maucieri, C., Nicoletto, C., Zanin, G., Birolo, M., Trocino, A., Sambo, P., Borin, M., Xiccato, G. (2019). Effect of stocking density of fish on water quality and growth performance of European Carp and leafy vegetables in a lowtech aquaponic system. PLOS ONE, 14(5), e0217561.

https://doi.org/10.1371/journal.pone.0217561

Mengistu, S.B., Mulder, H.A., Benzie, J.A.H., Komen, H. (2020). A systematic literature review of the major factors causing yield gap by affecting growth, feed conversion ratio and survival in Nile tilapia (Oreochromis niloticus). Reviews in Aquaculture, 12(2), 524-541.

ttps://doi.org/10.1111/raq.12331

Mohapatra, S., Chakraborty, T., Prusty, A.K., Pani Prasad, K., Mohanta, K.N. (2014). Beneficial effects of dietary probiotics mixture on hemato-immunology and cell apoptosis of Labeo rohita fingerlings reared at higher water temperatures. PLOS ONE, 9(6), e100929.

https://doi.org/10.1371/journal.pone.0100929

Munirasu, S., Ramasubramanian, V. (2017). Effect of Probiotics diet on growth and biochemical performance of freshwater fish Labeo rohita fingerlings. Journal of Entomology and Zoology Studies, 5(3), 1374-1379.

Nayak, S.K. (2010). Probiotics and immunity: a fish perspective. Fish \& Shellfish Immunology, 29(1), 2-14. https://doi.org/10.1016/j.fsi.2010.02.017

Olvera-Novoa, M.A., Campos, S.G., Sabido, M.G., Martínez Palacios, C.A. (1990). The use of Alfa alfa leaf protein concentrates as a protein source in diets for tilapia (Oreochromis mossambicus). Aquaculture, 90(3), 291-302.
https://doi.org/10.1016/0044-8486(90)90253-J

Panase, P., Mengumphan, K. (2015). Growth performance, length-weight relationship and condition factor of backcross and reciprocal hybrid catfish reared in net cages International Journal of Zoological Research, 11(2), 57-64. https://doi.org/10.3923/ijzr.2015.57.64

Parrino, V., Cappello, T., Costa, G., Cannavà, C., Sanfilippo, M., Fazio, F., Fasulo, S. (2018). Comparative study of haematology of two teleost fish (Mugil cephalus and Carassius auratus) from different environments and feeding habits. The European Zoological Journal, 85(1), 193-199. https://doi.org/10.1080/24750263.2018.1460694

Pechsiri, J., Yakupitiyage, A. (2005). A comparative study of growth and feed utilization efficiency of sex-reversed diploid and triploid Nile tilapia, Oreochromis niloticus L. Aquaculture Research, 36(1), 45-51.

https://doi.org/10.1111/j.1365-2109.2004.01182.x

Puente-Marin, S., Thwaite, R., Mercado, L., Coll, J., Roher, N., \& Ortega-Villaizan, M. D. M. (2019). Fish red blood cells modulate immune genes in response to bacterial inclusion bodies made of TNF $\alpha$ and a G-VHSV fragment. Frontiers in Immunology 10,1055.

https://doi.org/10.3389/fimmu.2019.01055

Rahman, Z., Mamun, A., Ahmad, I., Rashid, I. (2019). Influence of probiotics on the growth performance of sex reversed Nile tilapia (Oreochromis niloticus, Linnaeus, 1758) Fry. Journal of Aquaculture Research \& Development, 10(2), 8-14.

Rebouças, V.T., Lima, F.R. dos S., Cavalcante, D. de H., do Carmo E Sá, M.V. (2016). Reavaliação da faixa adequada de $\mathrm{pH}$ da água para o cultivo da tilápia do Nilo, Oreochromis niloticus L. Em águas eutróficas. Acta Scientiarum - Animal Sciences, 38(4), 361-368.

https://doi.org/10.4025/actascianimsci.v38i4.32051

Reyes-Becerril, M., Salinas, I., Cuesta, A., Meseguer, J., Tovar-Ramirez, D., Ascencio-Valle, F., Esteban, M. A. (2008). Oral delivery of live yeast Debaryomyces hansenii modulates the main innate immune parameters and the expression of immune-relevant genes in the gilthead seabream (Sparus aurata L.). Fish \& Shellfish Immunology, 25(6), 731-739.

https://doi.org/10.1016/j.fsi.2008.02.010

Riche, M., Garling, D. (2003). Feeding Tilapia in Intensive 
Recirculating Systems. North Central Regional Aquaculture Center, August, 0-4.

https://doi.org/10.1037/0894-4105.17.1.3

Roche, H., Bogé, G. (1996). Fish blood parameters as a potential tool for identification of stress caused by environmental factors and chemical intoxication. Marine Environmental Research, 41(1), 27-43.

https://doi.org/10.1016/0141-1136(95)00015-1

Rollo, A., Sulpizio, R., Nardi, M., Silvi, S., Orpianesi, C., Caggiano, M., Cresci, A., Carnevali, O. (2006). Live microbial feed supplement in aquaculture for improvement of stress tolerance. Fish Physiology and Biochemistry, 32(2), 167-177.

https://doi.org/10.1007/s10695-006-0009-2

Satheeshkumar, P., Ananthan, G., Kumar, D.S., Jagadeesan, L. (2012). Haematology and biochemical parameters of different feeding behaviour of teleost fishes from Vellar estuary, India. Comparative Clinical Pathology, 21(6), 1187-1191.

https://doi.org/10.1007/s00580-011-1259-7

Shoko, A.P., Limbu, S.M., Mrosso, H.D.J., Mgaya, Y.D. (2015). Reproductive biology of female Nile tilapia Oreochromis niloticus (Linnaeus) reared in monoculture and polyculture with African sharptooth catfish Clarias gariepinus (Burchell). SpringerPlus, 4(1).

https://doi.org/10.1186/s40064-015-1027-2

Silva, T.F.A., Petrillo, T.R., Yunis-Aguinaga, J., Marcusso, P.F., da Silva Claudiano, G., de Moraes, F.R., de Engrácia Moraes, J.R. (2015). Efectos del probiótico Bacillus amyloliquefaciens en el crecimiento, hematología y morfometría intestinal en tilapias del Nilo criadas en balsa jaula. Latin American Journal of Aquatic Research, 43(5), 963-971.

Simide, R., Richard, S., Prévot-D'Alvise, N., Miard, T., Gaillard, S. (2016). Assessment of the accuracy of physiological blood indicators for the evaluation of stress, health status and welfare in Siberian sturgeon (Acipenser baerii) subject to chronic heat stress and dietary supplementation. International Aquatic Research, 8(2), 121135.

https://doi.org/10.1007/s40071-016-0128-z
Soltan, M. A., Fouad, I. M., \& Elfeky, A. (2016). Growth and feed utilization of Nile tilapia , Oreochromis niloticus fed diets containing probiotic. Global Veterinaria, 17(5), 442450 .

Thomas, S., Egée, S. (1998). Fish Red Blood Cells: Characteristics and physiological role of the membrane ion transporters. Comparative Biochemistry and Physiology Part A: Molecular \& Integrative Physiology, 119(1), 79-86. https://doi.org/10.1016/S1095-6433(97)00404-2

Uddin, S., Hossain, M., Ahamed, S., Iqbal, M., Akter, M. (2017). Status of drugs, chemicals and antibiotics usages in freshwater aquaculture activities at Jaintapurupazila of Sylhet, Bangladesh. Algerian Journal of Environmental Science and Technology, 3(2), 5-10.

Xia, Y., Wang, M., Gao, F., Lu, M., Chen, G. (2020). Effects of dietary probiotic supplementation on the growth, gut health and disease resistance of juvenile Nile tilapia (Oreochromis niloticus). Animal Nutrition, 6(1), 69-79.

https://doi.org/10.1016/j.aninu.2019.07.002

Yamashita, M.M., Pereira, S.A., Cardoso, L., de Araujo, A.P., Oda, C.E., Schmidt, É.C., Bouzon, Z.L., Martins, M.L., Mouriño, J.L.P. (2017). Probiotic dietary supplementation in Nile tilapia as prophylaxis against streptococcosis. Aquaculture Nutrition, 23(6), 1235-1243.

https://doi.org/10.1111/anu.12498

Yuan, Y., Yuan, Y., Dai, Y., Gong, Y. (2017). Economic profitability of tilapia farming in China. Aquaculture International, 25(3), 1253-1264.

https://doi.org/10.1007/s10499-017-0111-8

Yue, H., Huang, X., Ruan, R., Ye, H., Li, Z., \& Li, C. (2020). Effect of dietary lipid on growth, body composition, serum biochemistry and hepatic metabolite alteration in Chinese rice field eel (Monopterus albus) fingerlings. Aquaculture Nutrition, 27, 63-76. https://doi.org/10.1111/anu.13165 